\title{
Flowers retail trade market: an application of Porter's Strategic Taxonomy
}

\author{
Adilson Anacleto $^{1 *}$, Luciane Scheuer ${ }^{1}$, Amanda Casubek Cury $^{1}$, Luana Rodrigues de Azevedo de Oliveira ${ }^{1}$
}

\begin{abstract}
The flowers retail trade has shown good potential for development in agribusiness, despite the growth. Thus, in order to support a better understanding of the current scenario, it is presented the result of a research that sought to promote a classification by Porter's Strategic Taxonomy, revealing what were the main lasting competitive advantages in the segment. In this context, a descriptive exploratory research was carried out between July and October 2019, where 23 flowers retailers in Paraná Coast, South of Brazil agreed to participate in the survey. The result of the classification of Porter's taxonomy revealed that most retailers use the differentiation strategy $(n=52 \%)$, followed by the focus strategy $(n=48 \%)$, with no retailers that adopt the strategy of leadership in cost. The main threats from competitive forces were the bargaining power of the suppliers and the threat of substitute products. The main commercial tactics, which in the interviewees' perception resulted in lasting competitive advantage, were the quality of the flowers sold, the experience in the flower segment that generated differentiated service, the offer of products different from the traditional ones and lower prices. The strategic typologies of Porter's taxonomy adopted by retailers in Paraná Coast, in the current scenario, seem to be able to minimize the effects of competitive forces and they are able of generating sustainable competitive advantages.
\end{abstract}

Keywords: agribusiness, floriculture, flower trade, landscaping, cut flowers.

\section{Resumo}

Comércio varejista de flores: uma aplicação da Taxonomia Estratégica de Porter

O comercio varejista de flores tem apresentado bom potencial de desenvolvimento no agronegócio. Assim, visando subsidiar uma melhor compreensão do cenário atual, apresenta-se o resultado de pesquisa que buscou promover uma classificação pela Taxonomia Estratégica de Porter, revelando quais eram as principais vantagens competitivas duradouras no segmento. Neste contexto, foi realizada uma pesquisa exploratória descritiva entre julho a outubro de 2019, em que 23 varejistas de flores do litoral do Paraná concordaram em participar da pesquisa. O resultado da classificação da taxonomia de Porter revelou que a maioria dos varejistas utiliza a estratégia de diferenciação $(n=52 \%)$, seguido pela estratégia de enfoque $(n=48 \%)$, sendo que não foram encontrados varejistas que fizessem a adoção da estratégia de liderança em custo. As principais ameaças oriundas das forças competitivas eram o poder de negociação dos fornecedores e a ameaça de produtos substitutos. As principais táticas comerciais, que na percepção dos entrevistados resultavam em vantagem competitiva duradoura, eram a qualidade das flores vendidas, a experiência no segmento de flores que gerava atendimento diferenciado, a oferta de produtos diferentes dos tradicionais e menores preços. As tipologias estratégicas da taxonomia de Porter adotadas pelos varejistas no litoral do Paraná, no cenário atual, aparentemente se confirmaram como capazes de minimizar os efeitos das forças competitivas e são capazes de gerar vantagem competitiva sustentável.

Palavras-chave: agronegócio, floricultura, comércio de flores, paisagismo, flores de corte

\section{Introduction}

Starting with the transformation of the term agriculture to agribusiness, the globalization has caused several changes, also in the way of managing it, including the concern with factors that were not previously evident, such as performance, quality, innovation, efficiency and competitiveness. The observation of the agribusiness, the productive chains and their practices, allows a better understanding of the productive chains, which consequently allows the development of effective strategies that can promote the development of the small producer communities in line with the globalized world (Maia, 2016).

${ }^{1}$ State University of Paraná, Administration Department, Paranaguá Campus, Paraná-PR, Brazil.

*Corresponding author: adilson.anacleto@unespar.edu.br

Received Feb 28, $2020 \mid$ Accepted May 02, 2020| Available online May 11, 2020

Licensed by CC BY 4.0

https://doi.org/10.1590/2447-536X.v26i2.2154

Area Editor: Márkilla Zunete Beckmann-Cavalcante 
There was a wide process of commoditization of products in the flower production chain, due to the strengthening of globalization, and international trade borders have been broken especially due to trade agreements such as the Eurozone and Mercosur (Junqueira and Peetz, 2014; Anacleto et al., 2017; Ferreira, 2019).

The Southern region of Brazil is the second in the national ranking of flower cultivation and there is a constant development and solidification of this segment that has achieved high levels of progress, becoming a business opportunity for small and medium entrepreneurs. Specifically, in relation to Paraná State, the Agência Nacional de Notícias (AEN, 2016) reported that in 2014 there was a growth of $17 \%$ in the gross value of production compared to 2013, when the segment, in Paraná, reached a revenue of $\mathrm{R} \$ 115.2$ million. From that period on, the sector reached an annual growth rate of $8.9 \%$, a significant increase compared to other Brazilian regions (Andrade, 2019; Muraro et al., 2019).

According to Anacleto (2016) the local flower trade in Paraná, has shown similar growth to other Brazilian regions, however specifically related to the coastal region, this trend is not accentuated. Among the difficulties Anacleto (2016) and Ferreira (2019) point out the few strategies suitable for retail trade, which fail in promoting flower sales under the same conditions as in other Brazilian regions such as Brasília, São Paulo and Porto Alegre, where the consumption is always $40 \%$ higher than that practiced in the region. Kotler (2011) says that is essential to investigate about what tactics these companies are using, and from that point on, detecting which factors are generating competitive advantage.

From the twentieth century onwards, it was intensified the search for business models that considered beyond the momentary performance, the issues of the organization with the environment and related to the competitive advantages. Among the various strategic taxonomies that had greater acceptance in the corporate context, it is highlighted the Porter's generic strategy (2008), which proposes three distinct categories: the product differentiation, the leadership through cost and the strategy of concentration in the market niche also called focus strategy as well as highlighting the five competitive forces of influence in the segment: rivalry among the competitors; customers' bargaining power; suppliers' bargaining power; the risk of new competitors entry; and the threat of substitute products.

In this sense Porter (2008) says that the key to sustainable and lasting growth is the demarcation of a position that is less vulnerable to the opponents' attack and less exposed to the activities of the customers, the suppliers and the substitute products, whether they are new companies, or already established in the market. In this context, the detailed knowledge about the retail market can result in a collaborative flow of information, in order to guide production in the field, improving the efficiency and competitiveness of the production chain in Paraná Coast, favoring the meeting of customers' needs, which is classified as an indispensable factor for commercial positioning (Kotler, 2011). Specifically for the case of the retail market of flowers, what is observed the absence of studies that reveal the market positioning model of the retail trade of flowers (Anacleto, 2016; Muraro et al., 2019).

Thus, investigating the strategic management relationships among managers in relation to the segment in which they are operating is essential in the proposition of models in order to create business opportunities (Ferreira, 2019). In this sense, this study has in its general context the goal of promoting a diagnosis of the applicability of the strategic management model related to Porter's Taxonomy in the retail trade of flowers in Paraná Coast. Then, it was sought to answer the following questions: Is it possible to promote a classification of Porter's taxonomy in the flower retail trade in Paraná Coast? Do flower retailers in Paraná Coast see themselves in the Porter's taxonomic classification which were included? What were the strategies adopted by the managers that result in a competitive advantage for the retailers in the flower production chain? Such questions were answered through interviews with 23 flowers shops managers from Paraná Coast, as would be discussed below.

\section{Material and Methods}

Initially, in order to obtain information about flower retailers in Paraná Coast, a survey was carried out at the Trade Association in the cities of this region. Paraná Coast, located in the South of Brazil, was the selected region, because according to Anacleto et al. (2017) this region has a strong potential for the production and commercialization of flowers, associated to a growing increase in per capita income, in addition this region has a population with more than 250,000 inhabitants. Also, according to the authors, this region receives two million tourists during the summer with the potential to consume flowers. The regional pole city currently has the seventh largest financial collection in the State, being classified as a medium-sized city, which has per capita conditions and consumption of flowers similar to other 160 cities in the country.

Subsequently, between July and October 2019, according to the methodological proposal of Peinado and Fernandes (2012), an exploratory-descriptive research was carried out in 31 retail stores in Paraná Coast as the locus of the research, all of them were visited and 23 flowers shops managers agreed to participate in the research, when a semi-structured questionnaire divided into five blocks was applied as a data collection instrument.

The first block aimed to identify how the processes of the flower retailer trade were established, the commercial strategies adopted that, in the interviewees' perception, generated competitiveness, as well as the influencing factors in the retail establishment.

The second block was adapted from the studies proposed by Gimenez et al. (1999) who organized a set of questions with alternatives and answers, which sought to ascertain the typology of the strategy adopted by the company based on the strategic taxonomy object of the investigation. In this block the questionnaire was adapted in order to verify the Porter's Strategic Taxonomy (2008). 
The retail establishments, in a general context, adopted low-cost flowers in their sales line-up, such as species of violets, daisies, chrysanthemums and plants for external gardening, so the object of this study went beyond the generalist trading system, promote a classification of the Porter's taxonomy (2008) and find out which of the typologies of this model generated the greatest competitive advantage for the retailers in the region studied.

Each one of the eighteen questions in the second block contained three alternative answers. The alternative "A" pointed to a company that used the global leadership strategy in costs; The alternative "B" for a company that adopted the product differentiation strategy; the alternative " $\mathrm{C}$ " for a company that explored niches and markets in the focus strategy. The recurrence of alternative determined the predominance of the strategic type of the company by Porter's taxonomy, that is, after completing the questions in the block, it was verified which of the alternatives (A, B or C) the interviewee had the highest sum, which automatically promoted the classification of generic strategy by Porter's taxonomy.

After analyzing the typology in which the respondent was classified, a text was made available with an explanation of the characteristics of each typology, and the respondent was asked whether he/she agreed with the taxonomic classification obtained. In this phase, from 31 contacted, only 23 agreed to answer the questions proposed in the field research, since they agreed to be the assigned classification.

In the third block there were questions that sought to investigate the presence and influence of Porter's five competitive forces on the perception of the flower retailer in Paraná Coast, as well as what were the strategies that, in the perception of the interviewees, could mitigate the problems generated by the five competitive forces. Porter (2008) considers that there are five competitive forces among companies, and that they must be analyzed in order to develop an efficient strategy: threat from new competitors; threat of substitute products; customers' bargaining power; suppliers' bargaining power and finally the rivalry among competitors, each of which has its own competitive strengths

The fourth and last block contained questions about the professional information of the respondents, as well as the company, and in the interviewee's self-perception, what were the strategic skills most valued in the company and, what were the strategies adopted that, in the perception of the interviewees resulted in a competitive advantage to the retailer and the flower production chain sector. The definition of business strategies in the segment becomes essential to the development of the activity, because it allows to identify the short and long term objectives in line with the mission and vision of the future, resulting in planned attitudes that promote the company interaction with the environment in a competitive way (Ferreira, 2019).

After completing the data collection according to what was proposed by Padua (2019), the field research results were discussed with regard to the implications of the reality observed in the context of the retail flower trade in relation to the strategic typology proposed by Porter (2008) by analyzing the data triangulation (secondary documents, interviews and researchers' observations).

The understanding of the scenario of a production chain according to Anacleto (2016) can be outlined from the characterization of the forms of action of the agents involved from the production phase in the field to the final consumer. Based on this knowledge, it is possible to establish the similarities and discrepancies that there is in each segment. In this sense Gimenez et al. (1999) suggests that in order to achieve the desired levels of understanding one of the alternatives is to establish processes that generate a taxonomic grouping of the segments of the production chain and which reveal the characteristics in common, as well as also reveal the generic strategies adopted by the segment.

\section{Results}

The field research was answered by 23 traders distributed in all the municipalities from Paraná Coast. The study showed that the average age of the interviewees was 45 years old, the majority of them $(n=52 \%)$ completed high school education.

The study also revealed that the majority of the respondents was female $(n=70 \%)$ and that they also were the owner of the establishments, and all of them defined their companies as a family business.

The retail management system was carried out in a similar way in the establishments that were visited, and the flower shops managers used to buy flowers from wholesalers in Curitiba and Joinville $(\mathrm{n}=52 \%)$, another part of the interviewees $(n=26 \%)$ preferred to buy in the area of flowers at Ceasa and only when necessary from wholesalers, and part of the interviewees $(n=22 \%)$ purchased flowers for resale in multiple channels being them: wholesalers, rural producers, Ceasa and also from other retailers.

The results of Porter's Taxonomy Classification (2008) revealed that most retailers used the differentiation strategy ( $\mathrm{n}=52 \%$ ), followed by the focus strategy $(\mathrm{n}=48 \%)$, with no retailers found that adopted the cost leadership strategy. After the classification by knowing the characteristics of the typology that they were classified, $92 \%$ of the interviewees recognized themselves in the typology.

The flower retailers showed a low level of concern about the market implications related to the Porter's five competitive forces (Table 1). 
Table 1. Level of concern of flower traders in Paraná coast related to the five competitive forces proposed by Porter

\begin{tabular}{|c|c|c|c|}
\hline Competitive Forces & Do not worry & Little worried & Extremely worried \\
\hline Entry of new competitors & 16 & 5 & 2 \\
\hline Rivalry among the competitors & 16 & 4 & 3 \\
\hline Bargaining power of customers & 15 & 3 & 5 \\
\hline Bargaining power of suppliers & 2 & 9 & 12 \\
\hline The threat of substitute products & 5 & 6 & 12 \\
\hline
\end{tabular}

The main difficulties pointed out by the interviewees and which were related to the competitive forces were: the increase of flowers price by the suppliers and the low quality of the product, since often the low quality of the flowers, makes the consumer look for a substitute product, mainly in the case when the purchase of flowers is for a gift (Table 2).

Table 2. Main difficulties related to the five competitive strengths of Porter Taxonomy faced by flower retailers in Paraná Cost ( $\%$ of problems cited)

\begin{tabular}{|c|c|c|}
\hline Main Difficulties & $\begin{array}{l}\text { Relationship with } \\
\text { competitive forces }\end{array}$ & $\begin{array}{c}\text { Percent } \% \\
\text { of quote by businessmen }\end{array}$ \\
\hline Increase in flower prices by suppliers & Bargaining Power of Suppliers & 78 \\
\hline Quality of the product received at the flower shop & Bargaining Power of Costumers & 78 \\
\hline Lack of fidelity to flower consumption & Threat of substitute products & 60 \\
\hline Lack of periodicity of population consumption & Bargaining Power of Costumers & 60 \\
\hline $\begin{array}{c}\text { Reduced diversity of flowers offered by } \\
\text { wholesalers }\end{array}$ & Bargaining Power of Suppliers & 56 \\
\hline $\begin{array}{l}\text { Seasonality of the product in relation to } \\
\text { commemorative dates }\end{array}$ & Bargaining Power of Costumers & 56 \\
\hline $\begin{array}{l}\text { Freight cost when it is needed to buy from other } \\
\text { regions especially Holambra }\end{array}$ & Bargaining Power of Suppliers & 43 \\
\hline Online market growth & Bargaining Power of Costumers & 43 \\
\hline Many new flower shops in the region & Entry of new competitors & 21 \\
\hline Unfair competition & Rivalry among competitors & 13 \\
\hline
\end{tabular}

Multiple citation issues

The commercial strategies that managers adopted as a way to reduce the impact of the competitive forces described by Porter's Taxonomy (2008), and that allowed them to stand out in relation to the offer of competing products and services, they were somewhat similar to all establishments visited (Table 3). 
Table 3. Commercial strategies adopted by flower retailers in Paraná Coast in order to reduce the impact of the five competitive forces $(n=23)$

\begin{tabular}{|c|c|c|}
\hline & Strategies adopted by retailers & Adoption index \% \\
\hline 1 & Quality of flowers offered & 87 \\
\hline 2 & Experience in the flower segment that generates differentiated service & 65 \\
\hline 3 & Offering products different from traditional ones & 44 \\
\hline 4 & Offer lowest price & 42 \\
\hline 5 & Promotion on social networks & 42 \\
\hline 6 & Offer of promotions and loyalty benefits & 26 \\
\hline 7 & Customization of products offered & 26 \\
\hline 8 & Expansion of products related to flowers offered to customers \\
\hline 9 & Fast deliveries & 26 \\
\hline 10 & Ease of payment & 9 \\
\hline
\end{tabular}

Multiple citation issues

\section{Discussion}

The high performance of an organization is related to the actions of those who lead it and in order to keep it ahead of the competitors' initiatives, it is essential to develop skills that can reduce improvisation. In this context, the importance of planning for the competitive advantage generation is emphasized. On this matter, Ferreira (2019), states that products and services need to have constant innovations and that the most competitive companies in the market are those which focus on offering differentiated solutions to their customers. This statement could be supported by the researched findings since that managers perceived themselves as belonging to the strategy of focus and differentiation and at the same time, they did not notice themselves in the cost leadership strategy.

The absence of the cost leadership strategy may lie in the fact that, according to Porter (2008), this type of leadership basically uses the tactic of limiting competitors' capacity by reducing costs in all areas, and thus obtaining commercial control of a fraction of the market, also called market share. This model requires economy on a large scale, conditions did not observe in the present study, and although it was observed that two of the retailers also declared themselves as producers, they reported that their productions were not enough to meet the demands of their flower shops and they also needed to purchase products from wholesalers. In this sense, what was perceived with the results of the field research is that within the socioeconomic context of the interviewees, they do not fit this strategy because they do not have bargaining power and they also have difficulty in buying and producing on a larger scale in order to use this strategy.

Thus, probably the cost leadership strategy was not perceived among the interviewees since the purchase of flowers from wholesalers and other resellers limited the cost margin, whose control was not in the decision of retailers, but in other segments of the production chain, in particular producers and wholesalers from other regions, which meant that profit margins were similar to all respondents in the flower trade from Paraná Coast.

The focus strategy was the second typology most cited among flower retailers in Paraná Coast, which contradicts previous studies that affirmed that, in general, in small companies the differentiation strategy is the most adopted, being this aspect is the main criticism to Porter's taxonomy (2008). This strategic typology is based on the proposition that by dominating a restricted market segment, the company will be able to supply the customer's needs more efficiently than its competitors. Although this typology reduces the number of customers, it can provide good returns, countering the low volume of sales in relation to costs and the high rate of profitability, since consumers who adopt this typology, have little sensitivity to pricing.

The offer of products to specific consumers and with greater purchasing power, allows the company to be able to defend itself against the five competitive forces. The justification for the adoption of this model among flower retailers lies in the fact that one of the main obstacles in the retail trade is precisely the offer of trivial, non-innovative and creative products, and it is possible to find the same products in almost all establishments. Thus, the offer of unique and higher value products arouses the attention of the customers and can lead to the consumption loyalty. The high presence of retailers, who call themselves linked to this strategic typology, may signal a trend of change in this commercial behavior, as consumers are increasingly demanding, even though the segmentation reduces the number of consumers of this type of product. 
The flowers most cited by retailers, who identified themselves in the focus strategy, were precisely those with the highest selling price in the flowers shops, with species such as tulips, orchids with blue coloring, roses imported especially from Colombia, roses in bell jars, rare orchids and bromeliads, or for collectors.

According to the interviewees ( $\mathrm{n}=48 \%$ ), among the reasons that led them to prioritize the adoption of the focus strategy, the location of the flower shop was first reported, which most of the time were in neighborhoods and central regions of the cities that were places with higher concentration of economic income. Another relevant issue is that a significant part of the managers interviewed (32\%) reported that they directed their offers to this audience due to the profitability in this type of operation that was higher than in the sales of traditional flowers.

The differentiation strategy was the typology of taxonomy proposed by Porter with the largest number of followers among the flower retailers in Paraná Coast, which contradicts previous studies that say that this strategy only adapts to large organizations, and that when it is applied to small organizations all companies would fit into a single typology (Gimenez et al. 1999; Peinado and Fernandes, 2012).

The reasons for the adoption of this strategic typology according to the interviewees are similar to the focus strategy, highlighting the location of the flower shops in regions with a higher concentration of economic income.

Different from the strategy of focus where retailers are concerned with offering flowers different from those found in the market, and they offer flowers imported from other regions and with a high cost to a small segment of the market, the differentiation strategy was characterized by creativity and innovation in the construction of processes which often transformed common products into differentiated ones, as in the case of the offer of flowers in arrangements and cachepots mentioned by most retailers $(\mathrm{n}=52 \%)$.

The use of flower arrangements (cachepots), in which several species are available in the same packages constituting a natural bouquet in pots, the use of environmentally friendly pots and packaging, the use of typical products from the region such as the use of decorative packaging with black liana (cipó preto), handicrafts and banana leaves, as well as the concern to offer flowers different from the traditional ones, reflects the behavior of the focus strategy where new components are added to the flower, the price being increased by the cost of new products and the service offered, creating a competitive differential for retailers that adopt this strategic typology.

Porter (2008) says that the differentiation aims at offering products or services that contain unique and different qualities from the traditional ones found by its customers. It is urgent to point out that the question of costs cannot be ignored since the consumer of this kind of business has less price sensitivity when compared to the generalist products, but at the same time they have greater price sensitivity than consumers classified in the focus strategy. Thus, the retailers use their experiences in the sector as indicators of the range of products that differ from the traditional market, as well as the market of focus, and the effective execution of this strategy within the limits of the customers also allows the retailer to have aboveaverage profitability, generating competitive advantage.

The differentiation strategy also has defenses against competitive forces, specifically in the case of rivalry among competitors, since the company opting for the differentiation overlaps the competitors, due to the fact that its customers are loyal to the products and services offered and less sensitive to prices. This profitability margin, neither so low nor so high, contributes to the creation of barriers of entrance by competitors and generates a more lasting competitive advantage. The profit margin obtained in this typology allows greater bargaining power with suppliers and also moderates the consumers' bargaining power (Porter, 2008).

One of the risks of this model is that companies, by segmenting their customers, limit the economy of scale (Porter, 2008), as this model requires investments in marketing and the development of new ways to offer flowers and products that can be successful in the retail trade. This experimentation process can generate a tradeoff, that is, a conflict situation, which can become costly to the company by experimenting various types of flowers and products in floral arrangements until an offer with good commercial power is available.

In relation to the five competitive forces, the bargaining power of suppliers is a pressing concern of the retailers interviewed $(\mathrm{n}=100 \%)$ and this competitive strength has a reduced impact on the tactic of diversifying supplier options, a common practice observed in this research. The diversification of purchases among several suppliers apparently reduces the influence of this competitive force in retail stores, since the managers always have purchasing alternatives if the price or quality are not as desired.

The influence of substitute products is a concern of the retailers, as it was observed during the field research that the flower shops started a product diversification process, in many cases offering products not linked to flowers, but with gifts from seasonal dates, time when there is a greater search for flowers. In this context it was possible to observe flower shops offering wines and other drinks, chocolates and stuffed animals that traditionally are substitute products for flowers, when the consumer seeks a gift from loved ones, as also reported by Anacleto et al. (2017). This practice reduces the competitive strength power of substitute products sold in other establishments and promotes profitability in the flower shop since when the customer does not find the desired flower, he can find substitute products in the flower shop and thus make the purchase.

However, the three competitive forces deserve careful attention, given that the present study revealed that they are receiving little attention from retailers, then these forces are: the costumers' bargaining power; the rivalry among competitors; the entry of new competitors. 
In this sense the first factor refers to the customers' bargaining power. The little attention given by retailers to this competitive force may be residing in the fact that the coastal region has high demand in relation to the fixed population, as well as the seasonal population, since in the summer season it rises more than ten times, which facilitates the flower trade. This combination of factors may be guaranteeing a high demand for flowers, making businessmen comfortable in the commercial aspects. The main tactics in reducing this competitive strength highlighted by the interviewees were to offer the most common plants at a lower price, the offer of promotions and benefits for loyalty purchases and the promotion of these tactics on social networks.

The rivalry among competitors was also detected as a competitive force with little action by retailers (Table 1), and the probable explanation for this situation may also lie, according to Anacleto (2016), in the relationship of high demand for flowers. So, the scenario reduces fierce competition and rivalry among competitors. Another factor that may be acting as mitigated one of this competitive force is that during the field research, it was observed that the flower shops were most often very distant from each other, which can reduce the effect of rivalry among competitors.

The entry of new competitors may constitute one of the most relevant competitive forces and little attention has been paid to this issue. According to Ferreira (2019), the risk of the entry of new competitors of larger size and with greater service capacity can put at risk the survival of these small retail businesses. Apparently, according to Anacleto (2016), the retail trade in Paraná Coast created a model of competitive advantage that made it the most strengthened segment of the production chain, in this case the adoption of the collective purchasing practice. The coordination and cooperation among the companies, groups of three to a maximum of four companies, result in a greater competitive capacity, especially by reducing costs. Also, according to the same author, the shared strategy in the retail segment goes beyond the simple barrier of collective purchasing, but it results from a modern system of cooperation where competitors see themselves as partners, and still create barriers to the entry of new competitors when necessary.

The strategic typologies of Porter's taxonomy (2008) adopted by retailers in Paraná Coast, in the current scenario, have apparently been confirmed as able of minimizing the effects of competitive forces and capable of generating sustainable competitive advantage. Competitive advantage is the result of strategic decisions, the skills acquired by managers, the way of attention to the customers and the capacity for innovation in the retail trade, but the competitive advantage is only sustained, if the competition has difficulties of imitating, or even to grant itself bargaining power that minimizes competitive forces.

\section{Conclusions}

The research revealed that Porter's taxonomy can be adapted to the study of small retail flower establishments, and the results of Porter's Taxonomy Classification (2008) revealed that most retailers perceived themselves as users of the differentiation strategy $(n=52 \%)$, followed by the focus strategy $(\mathrm{n}=48 \%$ ), however it was not observed the existence of retailers who adopted the cost leadership strategy.

The main threats from competitive forces were the bargaining power of suppliers and the threat of substitute products. The main strategies, in the perception of the interviewees that resulted in lasting competitive advantage were the quality of the flowers sold, the experience in the flower segment that generated differentiated service, the offer of products different from the traditional ones and the lowest price.

The strategic typologies proposed by Porter's taxonomy and adopted by retailers in Paraná Coast in the current scenario, apparently are able of minimizing the effects of the competitive forces and are capable of generating sustainable competitive advantage.

\section{Author Contribution}

A.A. ${ }^{0000-0003-1050-4643}$ and L.S. ${ }^{0000-0002-5307-3655}$ : Adviser of work, analysis and interpretation of data, critical review of the article, preparation and writing of the article, approval of the final version of the article. A.C.C. ${ }^{0000-0002-4869-7914}$ and L.R.A.O. ${ }^{0000-0001-9856-299 x}$ : research idea, elaboration of field questionnaire, field interviews with retailers, field analysis, data collection and analysis, interpretation, preparation and writing of the article.

\section{References}

AEN. Pequenos produtores ampliam cultivo de flores no Paraná. p.1, 2016. Available at: <http://www.aen. pr.gov.br> Accessed on November 18, 2019.

ANACLETO, A. Flowers supply chain in Paraná Coast - Brazil: an application of Miles and Snow taxonomy. Revista Capital Científico, v.14, n.1, p.10-25, 2016. DOI: http://dx.doi.org/10.5935/2177-4153.20160001

ANACLETO, A.; NEGRELLE, R.R.B.; CUQUEL, F.L.; MURARO, D. Profile and behavior of flower consumer: subsidies for marketing actions. Ceres, v.64. n.6, p.557-566. 2017. DOI: http://dx.doi.org/10.1590/0034$737 \times 201764060001$

ANDRADE, P. F. S. Análise da Conjuntura Agropecuária Safra 2015/2016: Floricultura. p. 11-15, 2015. Available at: <http://www.agricultura.pr.gov.br > Accessed on December 11, 2019.

GIMENEZ, F.A.P.; PELISSON, C.; KRUGER, E.G.S.; HAYASHI JR, P. Estratégia em pequenas empresas: uma aplicação do modelo de Miles e Snow. Revista de Administração Contemporânea, v.3, n.2, p.5374, 1999. DOI: http://dx.doi.org/10.1590/S141565551999000200004 
FERREIRA, K.B. Brazilian panorama and the prospects for international trade of bromeliads. American Journal of Engineering Research, v.8, n.5, p.36-41, 2019.

JUNQUEIRA, A.H.; PEETZ, M.S. O setor produtivo de flores e plantas ornamentais do Brasil, no período de 2008 a 2013: atualizações, balanços e perspectivas. Revista Brasileira de Horticultura Ornamental, v.20, n.2, p. 115120, 2014. DOI: https://doi.org/10.14295/rbho.v20i2.727

KOTLER, P. Marketing Management, 14 ed. New Jersey, EUA: Prentice Hall, 2011. 657p.

MAIA, A. G.; MIYAMOTO, B. C. B.; SILVEIRA, J. M. F. J. A adoção de sistemas produtivos entre grupos de pequenos produtores de algodão no Brasil. Revista de Economia e Sociologia Rural, v.54, n.2, p.203-220, 2016. DOI: http:// dx.doi.org/10.1590/1234.56781806-977900540201
MURARO, D.; CUQUEL, F.L.; NEGRELLE, R.R.B. Influência das instituições públicas no desenvolvimento do setor produtivo de plantas ornamentais. Revista Americana de Empreendedorismo e Inovação, v.1, n.1, p.32-38, 2019.

PEINADO, J.; FERNANDES, B.H.R. Estratégia, competências e desempenho em empresas de pet shop: evidências de um levantamento em Curitiba. Revista de Administração, v.47, n.4, p.609-623, 2012. DOI: https:// doi.org/10.5700/rausp1062

PORTER, M.E. Competitive strategy: techniques for analyzing industries and competitors. Free Press, New York, 2008. 436p.

PÁDUA, E. M. M. Metodologia da pesquisa: abordagem teórico-prática. Papirus Editora, Campinas, 2019. 144p. 